\title{
Köppen, Thornthwaite and Camargo climate classifications for climatic zoning in the State of Paraná, Brazil
}

\author{
Classificações climáticas de Köppen, Thornthwaite e Camargo para o zoneamento \\ climático do Estado do Paraná, Brasil
}

\author{
Lucas Eduardo de Oliveira Aparecido ${ }^{1 *}$, Glauco de Souza Rolim¹ , Jonathan Richetti ${ }^{2}$, \\ Paulo Sergio de Souza', Jerry Adriani Johann²
}

\author{
'Universidade Estadual Paulista "Julio de Mesquita Filho"/UNESP, Campus de Jaboticabal, Jaboticabal, SP, Brazil \\ 2Universidade Estadual do Oeste do Paraná/Unioeste, Centro de Ciências Exatas e Tecnológicas, Cascavel, PR, Brazil \\ *Corresponding author: lucas-aparecido@outlook.com \\ Received in February 5, 2016 and approved in May 16, 2016
}

\begin{abstract}
Climate is the set of average atmospheric conditions that characterizes a region. It directly influences the majority of human activities, especially agriculture. Climate classification systems (CCSs) are important tools in the study of agriculture, enabling knowledge of the climatic characteristics of a region. Thus, we aimed to perform the climatic characterization of the State of Paraná using the methods proposed by Köppen and Geiger (1928), modified by Trewartha (1954) (KT), Thornthwaite (1948) (TH) and Camargo (1991) and modified by Maluf (2000) (CM), using data from the European Center for Medium-Range Weather Forecast (ECMWF) model. The results of spatial interpolation (virtual stations) were performed using the Kriging method in spherical shape with one neighbour and resolution of $0.25^{\circ}$. The CCSs displayed the ability to separate the warm and dry from cold and wet regions. The most predominant climates were $\mathrm{Cfa}$ (temperate humid with hot summers), C, rA'a' (sub-humid with little water deficiency, megathermal) and ST-UMi (humid subtropical with dry winter), according to KT, $\mathrm{TH}$ and CM, respectively. CM is an intermediate CCS between $\mathrm{KT}$ and TH.
\end{abstract}

Index terms: Water balance; agriculture; climatic characterization; ECMWF.

\section{RESUMO}

Clima é o conjunto das condições atmosféricas médias que caracterizam uma região. Ele influencia diretamente a maioria das atividades humanas, em especial a agricultura. As classificações climáticas constituem um importante subsídio à agricultura, pois possibilita o conhecimento das características climáticas de uma região. Assim, objetivou-se caracterizar o clima do Estado do Paraná segundo os métodos propostos por Köppen e Geiger (1948) (KT), Thornthwaite (1948) (TH) e Camargo (1991) modificado por Maluf (2000) (CM), utilizando dados provenientes do modelo European Center for Medium-Range Weather Forecast (ECMWF). A interpolação espacial dos resultados (estações virtuais) foi feita pelo método de krigagem pelo modelo esférico com um vizinho e resolução de $0,25^{\circ}$. CCS separa as regiões quentes e secas das frias e húmidas. Os climas mais predominantes no Estado foram Cfa (temperado úmido com verão quente), C1rA'a' (subúmido com pequena deficiência hídrica, megatérmico) e ST-UMi (subtropical úmido com inverno seco), segundo os métodos de KT, TH e CM, respectivamente. A classificação climática de CM é um sistema intermediário entre de classificações de KT e TH.

Termos para indexação: Balanço hídrico; agricultura; caracterização climática; ECMWF.

\section{INTRODUCTION}

The State of Paraná has the $5^{\text {th }}$ largest economy in Brazil with regard to the agricultural and industrial sectors (Rodrigues; Moretto; Guilhoto, 2015). The agriculture in the State has great variability due to favourable growing conditions. Crops common to Paraná include soybean, maize, beans, coffee, cotton, wheat, cassava, sugarcane and diverse fruits. The State has high yields compared to other Brazilian States (CONAB, 2015). To maintain sustainability, a classification of the climate conditions in this State is needed to help with studies on crop zoning, irrigation projects and climate change. Climate determination facilitates the exchange of information for different purposes (Rolim et al., 2007).

Climate is the set of average atmospheric conditions that characterizes a region and strongly influences ecosystems (Jylhä et al., 2014). Climate is predicted using several factors such as latitude, longitude and altitude (Geng et al., 2014). Climatic conditions influence human activities, mainly agriculture and livestock (Dourado; Oliveira; Ávila, 2013). Thus, previous knowledge of the predominant climate in a region is fundamental to agricultural development (Rolim; Aparecido, 2015). 
Climate classifications are methods used to identify climatic types (Gallardo et al., 2013; Jacobeit, 2010) and spatial and seasonal climate variability (Bieniek; Bhatt; Thoman, 2012; De Castro et al., 2007). There are several climate classification systems (CCSs), such as Holdridge (1967), Flohn (1950), Camargo (1991), Köppen and Geiger, (1928) and Thornthwaite (1948). The latter two are the most used worldwide (Spinoni et al., 2014). CCSs are used in the validation of climate models (Jylhä et al., 2010; Belda et al., 2014), in climate change studies (Mahlstein; Daniel; Solomon, 2013) and in the definition of agricultural climatic zones (Rahimi; Ebrahimpour; Khalili, 2013).

The CCS of Köppen (Köppen; Geiger, 1928) (KT) is widely used (Larson; Lohrengel, 2014) in either its original or modified form (Silva; Moura; Klar, 2014). The model basically relates air temperature and precipitation to the distribution of natural vegetation (Elguindi et al., 2014), assuming that the natural vegetation is the best expression of the climate in a region (Gallardo et al., 2013).

The CCS of Köppen has been used in various European countries (De Castro et al., 2007), in China (Kim et al., 2008), in Brazil (Alvares et al., 2014) and worldwide (Peel et al., 2007); it has been used in studies of agrometeorology (Rolim; Aparecido, 2015), geography (Petersen; Sack; Gabler, 2012) and climatology (Rohli; Vega, 2012).

The CCS proposed by Thornthwaite (1948) (TH), in addition to air temperature and precipitation, uses potential evapotranspiration together with the elements of water balance to analyse climatic zones (Elguindi et al., 2014), defining a climate as dry or humid relative to the water needs of crops (Feddema et al., 2005). The TH CCS is the most indicated for agricultural applications (Rolim et al., 2007) but is not widely used due to having a complex symbology (Ács; Breuer; Skarbit, 2014).

The CCS of Camargo (1991) (CM) was developed in the agro-climatic aptitude survey conducted in Peru. This CCS was developed as a form of mapping divided into two basic parts, one for the thermal factor and another for water. A modification of the CM CCS was made by Maluf (2000) that sought to improve the definition of climate by adding a new class, "subtemperate", based on changes in the levels of average monthly temperature. The author's original proposal was to combine the simple classification of the Köppen CCS and thereby avoid the complex symbology of the TH CCS (Rolim; Aparecido, 2015). To date, the classification of climate using TH and CM is new for the State of Paraná.
Data from European Center for Medium-Range Weather Forecast (ECMWF) models are widely used worldwide because they have great advantages over data from weather stations in terms of speed in acquiring (in near real time) new data, providing coverage for the entire surface of the earth and having an absence of missing values. The literature contains several works that demonstrate a high correlation between the ECMWF model and surface data. For example, Moraes et al. (2012) calibrated the ECMWF data from surface data in the State of São Paulo and observed a high correlation.

Thus, we aimed to determine the climatic characterization of the State of Paraná according to the methods proposed by KT (1954), TH (1948) and CM (2000), using ECMWF data.

\section{MATERIALS AND METHODS}

\section{Data and Methods}

We used normal monthly average data for the State of Paraná, Brazil (Figure 1), collected by the ECMWF model (Global Reanalyses - ERA-Interim). The global ECMWF data have a spatial resolution of $0.25^{\circ}(27.8 \mathrm{~km})$ of latitude and longitude, obtained since 1979, on daily, ten-day or monthly scales.

The weather elements used were maximum and minimum air temperature $\left({ }^{\circ} \mathrm{C}\right)$, rainfall $(\mathrm{mm})$, and potential evapotranspiration (mm) from 1989 to 2014 . We employed 598 points in the State of Paraná that correspond to the virtual stations of the ECMWF model (Figure 1).

In the climatic classification models, it is necessary to establish the division of the months of the year in welldefined seasons, seeking an accurate classification of climate groups. In this paper, the season average and total calculations for temperature and rainfall were standardized in these periods (Table 1).

For each virtual station, the climate types were determined in accordance with the climatic classification systems of $\mathrm{KG}$, TH and CM.

\section{Köppen climate classification}

One of the most widely used CCSs in the world is the climate classification of Köppen (1900), refined by Köppen (1936) and later improved by Geiger (1954) and finally updated as Köppen-Trewartha (Trewartha, 1954) (KT). The KT CCS is symbolized by two or three characters; the first indicates the climate zone and is defined by the air temperature and rainfall, the second considers the seasonal distribution of rainfall and the third is the seasonal variation in air temperature (Figure 2). 


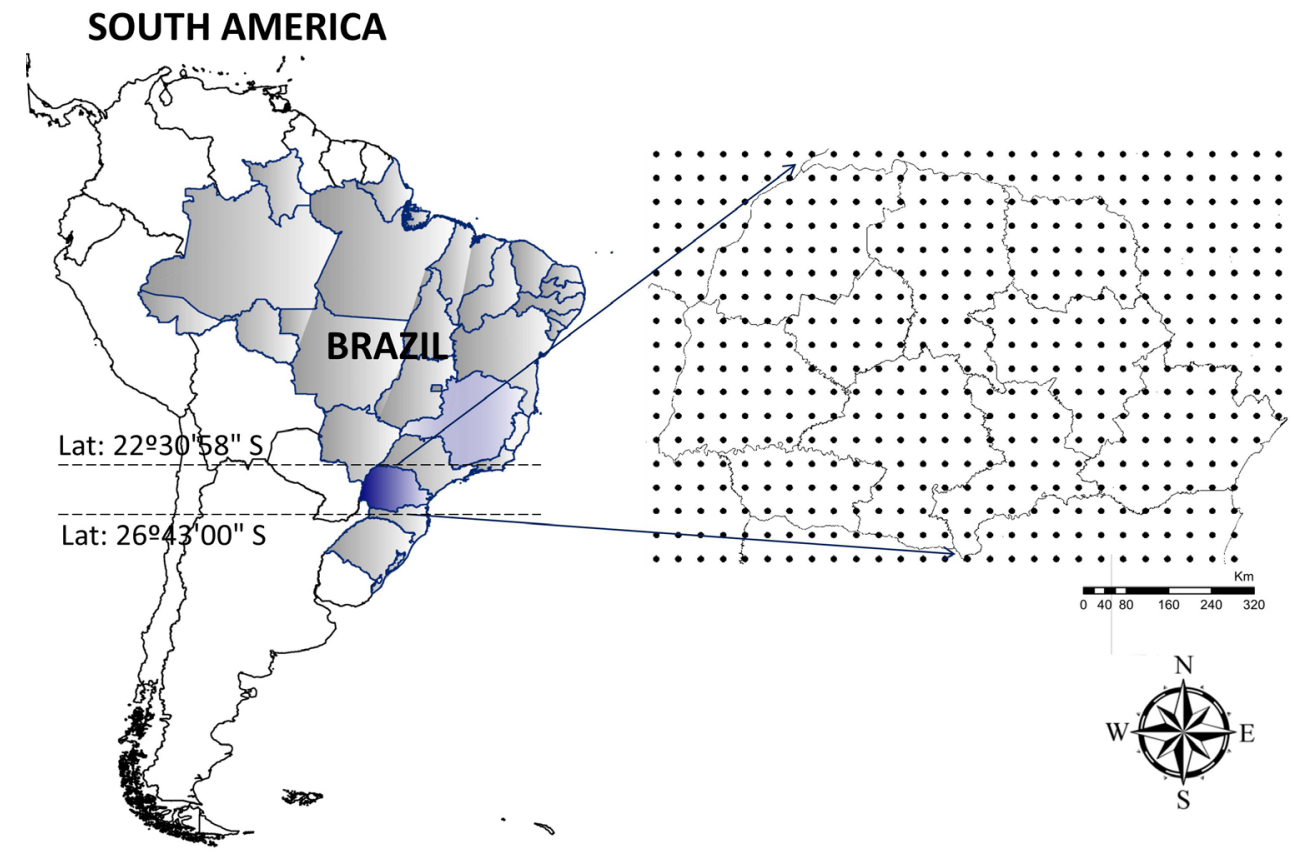

Figure 1: State of the Paraná with the virtual seasons of the ECMWF model. Black points are the ECMWF virtual stations.

Table 1: Convention for the seasonal period"1.

\begin{tabular}{cc}
\hline Season & Period \\
\hline Summer & $1 / 3 \mathrm{DEC}+$ JAN + FEB $+2 / 3 \mathrm{MAR}$ \\
Autumn & $1 / 3 \mathrm{MAR}+\mathrm{APR}+\mathrm{MAY}+1 / 3 \mathrm{JUN}$ \\
Winter & $2 / 3 \mathrm{UNN}+\mathrm{JUL}+\mathrm{AUG}+2 / 3 \mathrm{SEP}$ \\
Spring & $1 / 3 \mathrm{SEP}+\mathrm{OCT}+\mathrm{NOV}+2 / 3 \mathrm{DEC}$ \\
\hline${ }^{1}$ Source: Rolim and Aparecido (2015).
\end{tabular}

\section{Thornthwaite climate classification}

In the Thornthwaite (TH) CCS, the crop is viewed as the physical medium by which water is transported from the soil to the atmosphere. Thus, a type of climate is defined by TH as dry or humid based on the water needs of plants (water balance). The TH CCS was originally developed based on two equations that are direct functions of potential evapotranspiration (PET). The equations are the moisture effective index (Im, Equations 1 to 3 ) and the thermal efficiency index.

$\operatorname{Im}=\operatorname{Ih}-0.6 \times \operatorname{Ia}$

$\mathrm{Ih}=\frac{S U R}{P E T} \times 100$
$\mathrm{Ia}=\frac{D E F}{P E T} \times 100$

where Ih and Ia is hydric and aridity indexes, respectively. The ECMWF database supply directly the values of PET. These values are calculated by penman-monteith method as described by Srivastava et al. (2013). DEF (= PET AET) is water deficiency at the soil-plant system (mm), SUR is water surplus at the soil-plant system (mm), AET is the actual evapotranspiration (mm). DEF, SUR and AET are estimated by water balance model proposed by Thornthwaite and Mather (1955).

The TH CCS uses the following elements: index moisture (Table 2), hydric and aridity indices, water deficiency in summer (DEFS) and winter (DEFW), water surplus in summer (SURS) and winter (SURW) (Table 3), yearly potential evapotranspiration (PETY) (Table 4), summer potential evapotranspiration (PETS) and relative PET $($ PETR $=$ PETS/PETY.100) $($ Table 5).

\section{Camargo climate classification}

The CCS Camargo was developed to combine the simplicity of the KT CCS with the rationality of the TH CCS and was suggested by the author (Camargo, 2001) to be employed in agro-climatic zoning applications. The CCS Camargo modified by Maluf (2000) (CM) uses the 
following weather elements: annual mean air temperature (Ta), mean temperature of the coldest month (Tf), annual water deficit and surplus and the identification of months with water deficit (Table 6 and 7).

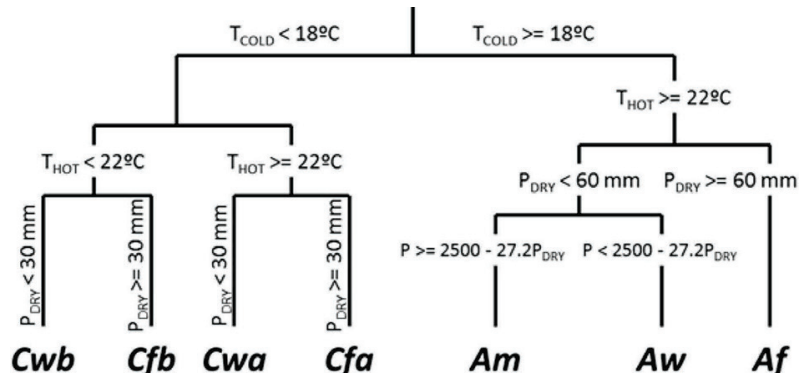

Figure 2: Fragment of climate classification system of Koppen and Geiger (1928) modified by Trewartha (1954) adapted from Rolim et al., (2007). Legend: TCOLD is air temperature of the coldest month $\left({ }^{\circ} \mathrm{C}\right)$; THOT is air temperature of the hottest month $\left({ }^{\circ} \mathrm{C}\right)$; PDRY is rainfall of the driest month $(\mathrm{mm})$; $\mathrm{P}$ is rainfall total $(\mathrm{mm})$; Cwb is humid subtropical with dry winter and temperate summer; $\mathrm{Cfb}$ is humid subtropical with oceanic climate, without dry season and temperate summer; Cwa is humid subtropical with dry winter and hot summer; Cfa is humid subtropical with oceanic climate, without dry season and hot summer; Am is tropical monsoon; Aw is tropical with dry winter and, Af is tropical without dry season.

Regarding the CM CCS, the monsoon classes (MO), dried (SE), sub-humid (SB) and humid (UM), can have defined dry periods that occur in different seasons. When this occurs, classes that have dry seasons are characterized by lower case letters (Table 8).
Geographic information system (GIS) data were used to generate the spatial interpolation of the results (virtual stations) for the entire State of Paraná via the Kriging method (Krige, 1951), using the spherical model with one neighbour and a resolution of $0.25^{\circ}$. Kriging is a univariate geostatistical method widely used for its efficiency in data interpolation (Carvalho; Assad, 2005; Viola et al., 2010; Carvalho; Assad; Pinto, 2012). The cartographic projection system was the conic of Lambert. Thus, it was possible to obtain the climatic zoning of the State of Paraná with the KT, $\mathrm{TH}$ and CM CCSs.

\section{RESULTS AND DISCUSSION}

\section{Air temperature in the State of Paraná}

Paraná had an annual mean air temperature $\left(\mathrm{T}_{\mathrm{Y}}\right)$ ranging between 15 and $24{ }^{\circ} \mathrm{C}$. The highest and lowest values were observed in the northwestern and southeastern parts of the state, respectively (Figure 3), results that were also observed by Minizzi and Caramori, (2011). The locality of Palmas showed a $\mathrm{T}_{\mathrm{Y}}$ below $16.5^{\circ} \mathrm{C}$.

\section{Rainfall in the State of Paraná}

The annual rainfall of the State of the Paraná ranges from 1,100 to $1,920 \mathrm{~mm}_{\text {year }}{ }^{-1}$, very similar to what was found in other studies (Alvares et al., 2014; Minizzi; Caramori, 2011) (Figure 4). We observed that the spatial variability is similar to that of the climatologically normal map presented by the meteorological service in Brazil (INMET, 2015). The annual rainfall gradually increases with latitude, likely because the action of polar masses (Cavalcanti; Kousky, 2009) (Figure 4). Annual rainfalls above $1,800 \mathrm{~mm}_{\text {year }}{ }^{-1}$ were mainly mapped mainly in the

Table 2: Climatic classes defined by Thornthwaite (1948). Im is moisture effective index.

\begin{tabular}{ccc}
\hline Classes Im & Climate description & Symbol \\
\hline $\operatorname{Im} \geq 100$ & Very Humid & $\mathrm{A}$ \\
$80 \leq \mathrm{Im}<100$ & & $\mathrm{~B}_{4}^{\prime}$ \\
$60 \leq \mathrm{Im}<80$ & Humid & $\mathrm{B}_{3}^{\prime}$ \\
$40 \leq \mathrm{Im}<60$ & & $\mathrm{~B}_{2}^{\prime}$ \\
$20 \leq \mathrm{Im}<40$ & & $\mathrm{~B}^{\prime}$ \\
$0 \leq \mathrm{Im}<20$ & Subhumid & $\mathrm{C}_{2}$ \\
$20 \leq \mathrm{Im}<0$ & Subhumid Dry & $\mathrm{C}_{1}$ \\
$-40 \leq \mathrm{Im}<-20$ & Dry & $\mathrm{D}$ \\
$-60 \leq \mathrm{Im}<-40$ & Arid & $\mathrm{E}$ \\
\hline
\end{tabular}


southeastern and southwestern parts of Paraná. Annual rainfall less than $1,200 \mathrm{~mm}_{\text {year }}^{-1}$ occurs in the northern regions, where Alvorada do Sul and Nova Londrina are located.

Table 3: Climatic sub-classes defined by Thornthwaite (1948). la is aridity index; Ih is hydric index; DEF is water deficit and SUR is water surplus.

\begin{tabular}{|c|c|c|c|c|}
\hline \multirow{2}{*}{ Climate description } & \multicolumn{2}{|c|}{ Classes la or Ih } & \multirow{2}{*}{ Sub-Climate description } & \multirow{2}{*}{ Symbol } \\
\hline & Intensity & Period & & \\
\hline \multirow{5}{*}{$\begin{array}{l}\text { Humid climate (A, B, } \\
\left.\qquad \mathrm{C}_{2}\right)\end{array}$} & $0 \leq 1 \mathrm{la}<16.7$ & & Without or with low DEF & $r$ \\
\hline & $167<1 a<33.3$ & $\mathrm{DEF}_{\mathrm{s}}>\mathrm{DEF}_{\mathrm{w}}$ & Moderate summer DEF & s \\
\hline & $10.1 \leq 1 d<33.3$ & $\mathrm{DEF}_{\mathrm{s}}<\mathrm{DEF}_{\mathrm{w}}$ & Moderate winter DEF & w \\
\hline & 1 a $>333$ & $\mathrm{DEF}_{\mathrm{S}}>\mathrm{DEF}_{\mathrm{W}}$ & Large summer DEF & $\mathrm{S}_{2}$ \\
\hline & $1 d \geq 33.3$ & $\mathrm{DEF}_{\mathrm{S}}<\mathrm{DEF}_{\mathrm{w}}$ & Large winter DEF & $w_{2}$ \\
\hline \multirow{5}{*}{ Dry climate $\left(C_{1}, D, E\right)$} & $0 \leq \mathrm{Ih}<10$ & & Without or with low SUR & $d$ \\
\hline & $10<\operatorname{lh}<20$ & $\mathrm{SUR}_{\mathrm{s}}>\mathrm{SUR}_{\mathrm{w}}$ & Moderate summer SUR & $\mathrm{s}$ \\
\hline & $10 \leq m<<0$ & $\mathrm{SUR}_{\mathrm{s}}<\mathrm{SUR}_{\mathrm{w}}$ & Moderate winter SUR & w \\
\hline & $\mathrm{lh}>33.3$ & $\mathrm{SUR}_{\mathrm{s}}>\mathrm{SUR}_{\mathrm{w}}$ & Large summer SUR & $\mathrm{S}_{2}$ \\
\hline & & $\mathrm{SUR}_{\mathrm{S}}<\mathrm{SUR}_{\mathrm{w}}$ & Large winter SUR & $\mathrm{w}_{2}$ \\
\hline
\end{tabular}

Table 4: Climatic classes based on potential evapotranspiration of year (PETY) defined by Thornthwaite (1948).

\begin{tabular}{ccc}
\hline Classes $\mathrm{PET}_{Y}$ & Climate description & Symbol \\
\hline $\mathrm{PET}_{Y} \geq 1140$ & Megathermal & $\mathrm{A}$ \\
$1140>\mathrm{PET}_{Y} \geq 997$ & & $\mathrm{~B}^{\prime}{ }_{4}$ \\
$997>\mathrm{PET}_{Y} \geq 885$ & Mesothermal & $\mathrm{B}^{\prime}$ \\
$885>\mathrm{PET}_{Y} \geq 712$ & & $\mathrm{~B}^{\prime}$ \\
$712>\mathrm{PET}_{Y} \geq 570$ & & $\mathrm{~B}^{\prime}$ \\
$570>\mathrm{PET}_{Y} \geq 427$ & Microthermal & $\mathrm{C}_{2}$ \\
$427>\mathrm{PET}_{Y} \geq 285$ & & $\mathrm{C}_{1}$ \\
$285>\mathrm{PET}_{Y} \geq 142$ & Tundra & $\mathrm{D}$ \\
$\mathrm{PET}_{Y}<142$ & Perpetual ice & $\mathrm{E}$ \\
\hline
\end{tabular}

Table 5: Climatic sub-classes based on relative potential evapotranspiration (PETR) defined by Thornthwaite (1948).

\begin{tabular}{cc}
\hline Classes PET $_{R}$ & Symbol \\
\hline PET $_{R}<48$ & $\mathrm{a}^{\prime}$ \\
$48 \leq \mathrm{PET}_{\mathrm{R}}<51.9$ & $\mathrm{~b}_{4}^{\prime}$ \\
$51.9 \leq \mathrm{PET}_{\mathrm{R}}<56.3$ & $\mathrm{~b}_{{ }_{3}}$ \\
$56.3 \leq \mathrm{PET}_{\mathrm{R}}<61.6$ & $\mathrm{~b}_{2}^{\prime}$ \\
$61.6 \leq \mathrm{PET}_{\mathrm{R}}<68$ & $\mathrm{~b}_{1}^{\prime}$ \\
$68 \leq \mathrm{PET}_{\mathrm{R}}<76.3$ & $\mathrm{c}_{2}^{\prime}$ \\
$76.3 \leq \mathrm{PET}_{\mathrm{R}}<88$ & $\mathrm{c}_{1}^{\prime}$ \\
$88 \leq \mathrm{PET}_{\mathrm{R}}$ & $\mathrm{d}^{\prime}$ \\
\hline
\end{tabular}


Table 6: Air temperature ranges of the climate classes of Camargo (1991)'.

\begin{tabular}{|c|c|c|c|c|}
\hline \multirow{2}{*}{$\begin{array}{l}\text { Yearly mean air temperature } \\
\qquad\left(\mathrm{T}_{\mathrm{y}^{\prime}}{ }^{\circ} \mathrm{C}\right)\end{array}$} & \multirow{2}{*}{\multicolumn{2}{|c|}{$\begin{array}{c}\text { Mean temperature coldest } \\
\text { month }\left(\mathrm{T}_{\text {COLD, }}{ }^{\circ} \mathrm{C}\right)\end{array}$}} & \multicolumn{2}{|c|}{ Climate } \\
\hline & & & Description & Symbol \\
\hline & & & & \\
\hline $3<T_{y} \leq 7$ & & & Frigid & FR \\
\hline $7<T_{y} \leq 12$ & & & Cold & $\mathrm{CO}$ \\
\hline $12<T_{y} \leq 18$ & or & $\mathrm{T}_{\text {COLD }} \leq 13$ & Temperate & TE \\
\hline $18<T_{y} \leq 22$ & and & $\mathrm{T}_{\text {COLD }} \leq 13$ & Subtemperate & STE \\
\hline $18<T_{y} \leq 22$ & and & $13<T_{\text {COLD }} \leq 20$ & Subtropical & ST \\
\hline $22<T_{y} \leq 25$ & or & $20<\mathrm{T}_{\text {COLD }}$ & Tropical & TR \\
\hline $\mathrm{T}_{\mathrm{y}}>25$ & & & Equatorial & EQ \\
\hline
\end{tabular}

'Source: Rolim and Aparecido (2015).

Table 7: Yearly surplus and deficit water of the climate classes of Camargo (1991)1.

\begin{tabular}{|c|c|c|c|c|}
\hline \multicolumn{3}{|c|}{ Water balance $(\mathrm{mm})$} & \multicolumn{2}{|c|}{ Climate } \\
\hline Deficit (DEF) & & Surplus (SUR) & Description & Symbol \\
\hline $\mathrm{DEF}>800$ & and & SUR $=0$ & Desert & DE \\
\hline $150<\mathrm{DEF} \leq 800$ & and & $S U R=0$ & Arid & AR \\
\hline DEF > 150 & and & $0<\mathrm{SUR} \leq 200$ & Dry & SE \\
\hline $\mathrm{DEF}>150$ & and & SUR > 200 & Monsoonal & MO \\
\hline $0<\mathrm{DEF} \leq 150$ & and & $0<\mathrm{SUR} \leq 200$ & Subhumid & SB \\
\hline $0<\mathrm{DEF} \leq 150$ & and & SUR > 200 & Humid & UM \\
\hline $\mathrm{DEF}=0$ & and & $200<$ SUR $\leq 1000$ & Very Humid & PU \\
\hline $\mathrm{DEF}=0$ & and & SUR $>1000$ & Extremely humid & SU \\
\hline
\end{tabular}

${ }^{1}$ Source: Rolim and Aparecido (2015).

Table 8: Classification symbol of the dry season defined by Camargo (1991).

\begin{tabular}{cc}
\hline Season & Symbol \\
\hline Spring & $\mathrm{p}$ \\
Summer & $\mathrm{v}$ \\
Autumn & $\mathrm{o}$ \\
Winter & $\mathrm{i}$ \\
\hline
\end{tabular}

'Source: Rolim and Aparecido (2015).

\section{Köppen Climatic Classification System for the State of Paraná}

The State of Paraná showed 2 groups $(\mathrm{A}$ and $\mathrm{C})$ and 4 climatic classes (Aw, Cwa, Cfa and $\mathrm{Cfb}$ ) according to the KT climate classification. Different results were found by Alvares et al. (2014), who classified the State of Paraná as only Cfa and Cfb using surface stations, and Sparovek, Van Lier and Dourado (2007), who classified Paraná as only Cf. These differences arose because the ECMWF model promotes better representation of the surface due to the presence of a much larger number of (virtual) stations.

The climate class with the highest predominance in the State of Paraná was the Cfa class, representing $50 \%$ of the area. The Cfb class was the second largest, representing $39.8 \%$ of the area and occurring in areas of high altitude, mainly in the highlands of Ponta Grossa and Curitiba. The Aw and Cwa classes were observed only in the north, accounting for only 5.7 and $4.3 \%$ of the State, respectively (Figure 5).

Regarding the Aw climate (humid tropical savanna), the driest season coincides with winter, and maximum precipitation in the driest months tends to be less than $60 \mathrm{~mm} \mathrm{month}{ }^{-1}$. The vegetation in these areas is usually undergrowth and bush (Sá Júnior et al., 2012). 
Regarding the Cwa climate (humid temperate climate with dry winter), summer is hot, with air temperatures in the hottest month above $22^{\circ} \mathrm{C}$; the average rainfall is less than $60 \mathrm{~mm}$ in at least one of the months of the season. The
Cfa (humid temperate climate with hot summer) and $\mathrm{Cfb}$ (humid temperate climate with moderately hot summer) are oceanic climates without a dry season (Sparovek; Van Lier; Dourado, 2007).

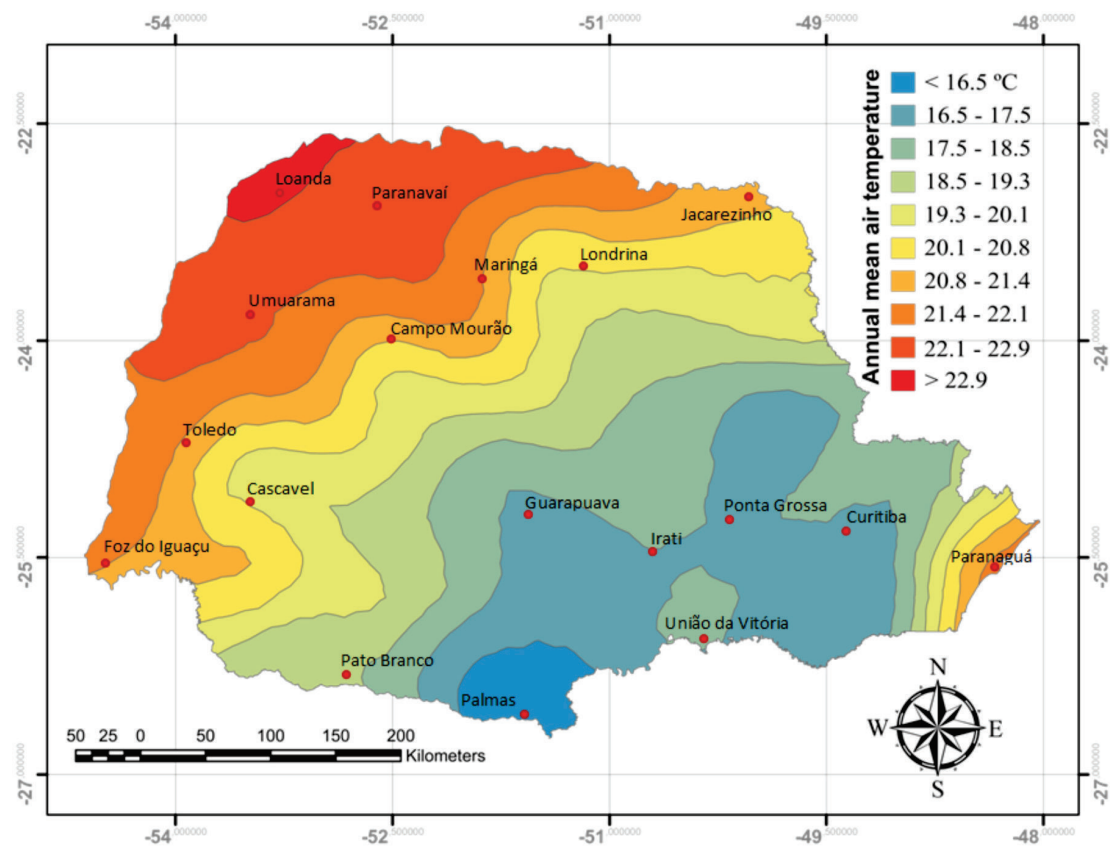

Figure 3: Annual mean air temperature map for State of Paraná, Brazil from ECMWF database.

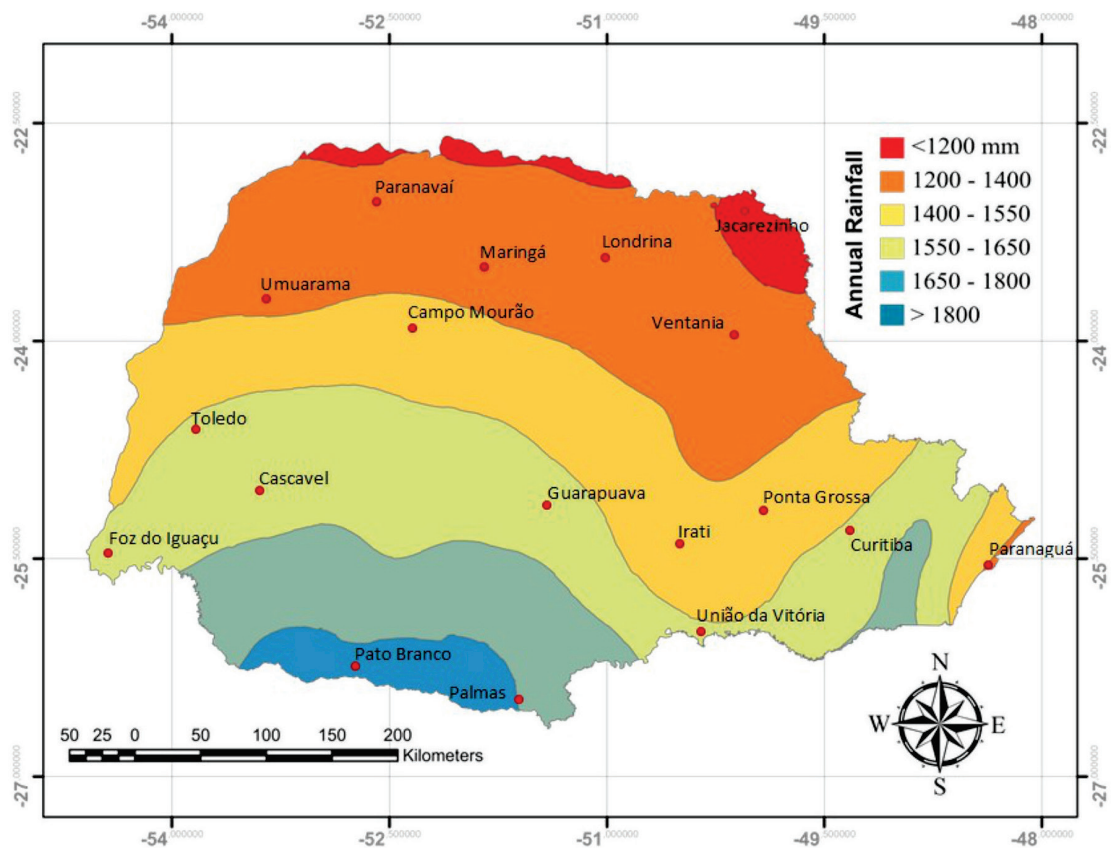

Figure 4: Total annual rainfall in the State of the Paraná, Brazil from ECMWF database. 


\section{Thornthwaite Climatic Classification System for the State of Paraná}

The climatic zoning using the TH climate classification for the State of the Paraná showed 12 climatic types. The $\mathrm{C}_{1}$ climates $\left(\mathrm{C}_{1} \mathrm{~d} \mathrm{~A}^{\prime} \mathrm{a}\right.$ ' and $\mathrm{C}_{1} \mathrm{w}^{\prime} \mathrm{A}^{\prime} \mathrm{a}$ ') were predominant in the higher latitudes (north of the Guarapuava plateau), and the $\mathrm{B}_{2}$ and $\mathrm{B}_{3}$ climates $\left(\mathrm{B}_{2} \mathrm{rB}_{4}{ }_{4} \mathrm{a}^{\prime}\right.$ and $\left.\mathrm{B}_{3} \mathrm{rB}_{3}{ }_{3} \mathrm{a}^{\prime}\right)$ were predominant in the lower latitudes of the State, as well as on the coast (Figure 6).

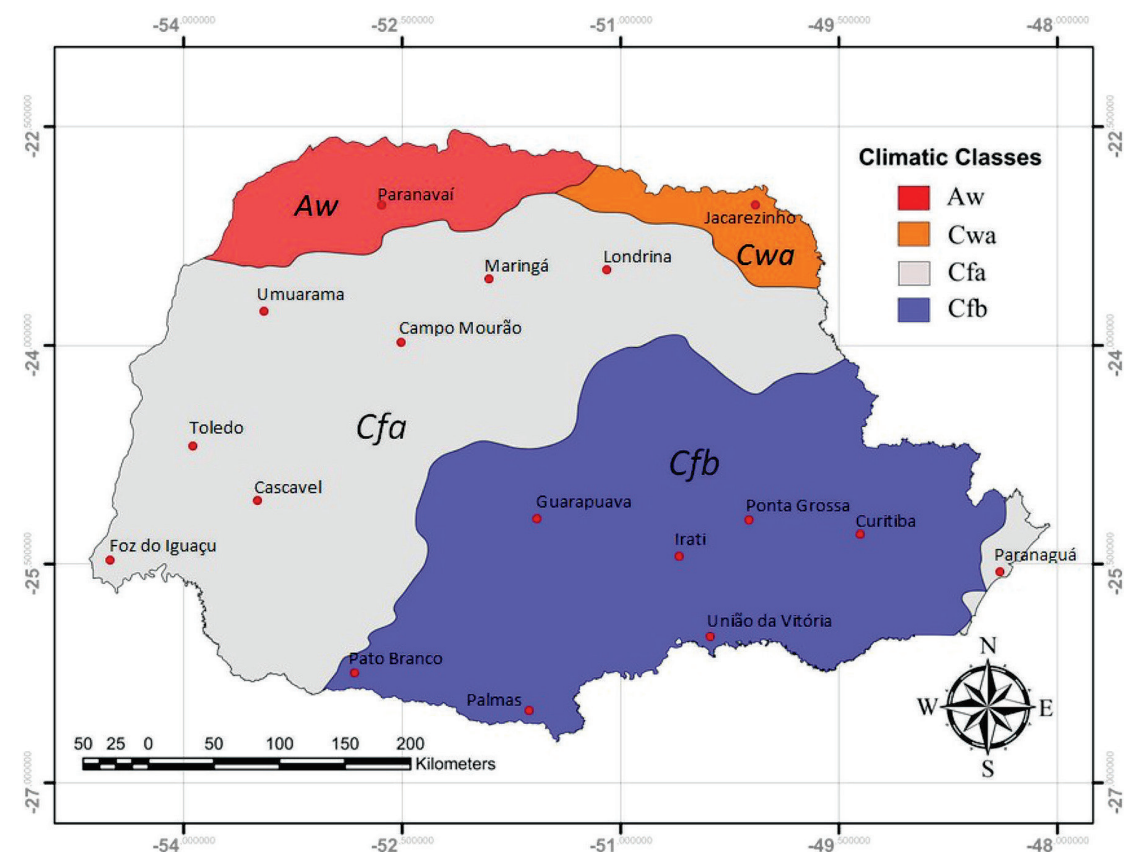

Figure 5: Climate zoning according to Köppen and Geiger (1928) modified by Trewartha (1954) obtained by ECMWF data.

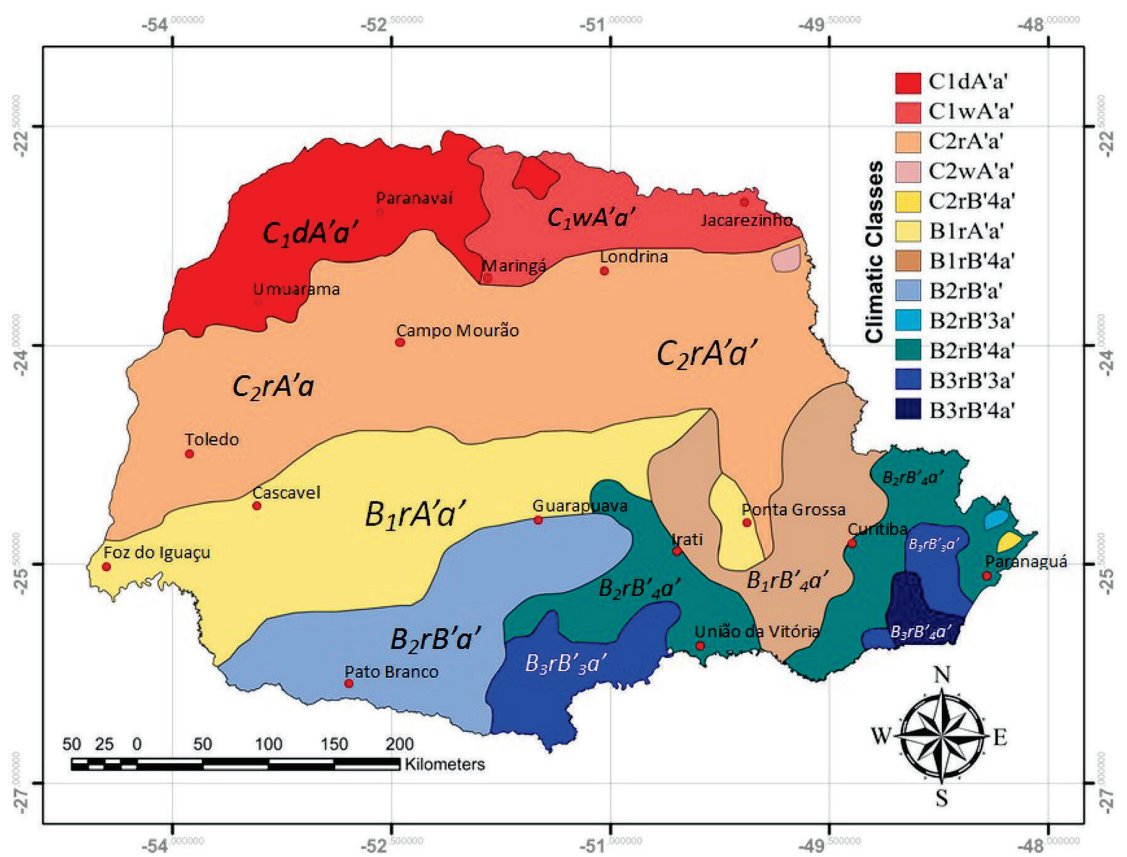

Figure 6: Climate zoning according to Thornthwaite (1948) obtained by ECMWF data. 
The climate type with the largest representation in the State of Paraná was the $\mathrm{C}_{1} \mathrm{rA}^{\prime} \mathrm{a}^{\prime}$, indicating a sub-humid temperature with little water deficiency, megathermal. This climate comprises $30.74 \%$ of the total area of the State and encompasses the Guarapuava plateau, Ponta Grossa and Curitiba. B1rA'a' (humid with little water deficiency, mega thermal) is the second most prevalent climate in the State $(21.28 \%)$. Cascavel and Foz do Iguaçu are in this climate class.

\section{Camargo Climatic Classification System for the State of Paraná}

The climatic zoning for the State of Paraná with CM CCS showed 3 classes according to the air temperature (TR is tropical, ST is subtropical, and TE is temperate) and 12 climate types. TR climates (TR-SEi and TR-MOi) were observed in the northwest and TE climates (TE-PU and TE-UMi) were predominant in the southeast of Paraná State (Figure 7). Rolim and Aparecido (2015), when classifying the São Paulo State, also observed that TR classes occur in the northwest region.

The climate type with the largest representation in Paraná was ST-UMi (humid subtropical with dry winter), with $24.6 \%$ of the total area; this climate area includes the cities of Cascavel, Toledo and Foz do Iguaçu. TE-UMi (temperate humid with dry winter) is the second most prevalent climate in the State (24.6\%); Curitiba, Ponta Grossa and Irati are in this climate class (Figure 7).

The high spatial density of data points used provided good precision in the characterization of climatic types in Paraná State. The use of a large number of points, as well as the method used in the data interpolation, exerts a strong influence on the final result of the classification (Rolim et al., 2007; Laslett, 1994). Deviations in the climatic classification can be minimized with the use of a greater number of points, as well as an interpolation most appropriate for the climate data (Sá Júnior et al., 2012).

KT CCS obtained a low number (4) of types of climates, while $\mathrm{CM}$ and $\mathrm{TH}$ showed an intermediate number, 11 and 12 climate types, respectively, in the State of Paraná (Figure 8). These results indicate the capacity of $\mathrm{KT}$ to separate climates in spatial macroscale and of $\mathrm{CM}$ and TH to separate climates on a local scale (mesoscale), as highlighted by Rolim and Aparecido (2015).

The most common KT climates in the State of Paraná were Cfa and $\mathrm{Cfb}$, with 148 and 118 areas, respectively. The most common CM climate was ST$\mathrm{UMi}$, with 73 areas, and the most common TH climate was $\mathrm{C}_{2} \mathrm{rA}^{\prime} \mathrm{a}$ ', with 91 areas. The $3 \mathrm{CCSs}$ showed a similar tendency in separating the hot and dry climates of the cold and humid regions (Figure 8). The majority of hot and dry $\mathrm{C}_{1}(\mathrm{TH})$ and $\mathrm{TR}(\mathrm{CM})$ climates occurred in the regions of Aw and $\mathrm{Cwa}(\mathrm{KT})$ climates, and the cold and wet TE $(\mathrm{CM})$ climates primarily occurred in the regions of $\mathrm{Cfb}$ (KT climate).

A climogram (Figure 9) is a classical representation of climate correlating two or more normal meteorological elements. The most humid place in Paraná had an annual rainfall of 1,800 $\mathrm{mm}_{\text {year }}{ }^{-1}$, with an annual PET $\geq 1,200 \mathrm{~mm}^{-1}$ yer $^{-1}$; this area was classified as Cfa, $\mathrm{B}_{2} \mathrm{rA}^{\prime} \mathrm{a}^{\prime}$ and ST-PU by KG, TH and $\mathrm{CM}$, respectively (Figure 9). The driest place had an annual rainfall of less than $1,250 \mathrm{~mm}^{\text {year-1 }}{ }^{-1}$ with an annual PET of approximately $1,450 \mathrm{~mm}^{2}$ year ${ }^{-1}$; this area was classified as Aw, $\mathrm{C}_{1} \mathrm{dA}^{\prime} \mathrm{a}^{\prime}$ and TR-SEi by KT, TH and $\mathrm{CM}$, respectively.

The KT CCS showed a less rigorous correlation with water availability in the environment. For instance, the climate type $\mathrm{Cfb}(\mathrm{KT})$ showed an annual rainfall ranging from $1,300 \mathrm{~mm}_{\text {year }}^{-1}$ to $1,850 \mathrm{~mm}_{\text {year }}{ }^{-1}$ and an annual PET ranging from $950 \mathrm{~mm}$ year $^{-1}$ to 1,200 $\mathrm{mm}$ year ${ }^{-1}$. The TH CCS was more accurate regarding information about the water budget, e.g., climates $\mathrm{B}_{2} \mathrm{rB}_{4}{ }^{\mathrm{a}}$ ', $\mathrm{B}_{3} \mathrm{rB}_{3} \mathrm{a}^{\prime}$, and $\mathrm{B}_{3} \mathrm{rB}_{4}{ }_{4} \mathrm{a}^{\prime}$, among others, occurred on the coast and in the same locations. The CM and KT CCSs were only TE-PU or ST-PU and Cfb, respectively. CM is an intermediate classification system between $\mathrm{KG}$ and $\mathrm{TH}$. These situations were expected because each CCS makes different assumptions in determining each type of weather (Rolim; Aparecido, 2015).

The temperature and precipitation changes of the CM CCS showed 11 types of weather, while KT and TH demonstrated 4 and 12 climates, respectively, showing that the CM and TH CCSs classified in mesoclimate scale and that the KT CCS classified in microclimate scale (Rolim et al., 2007). 


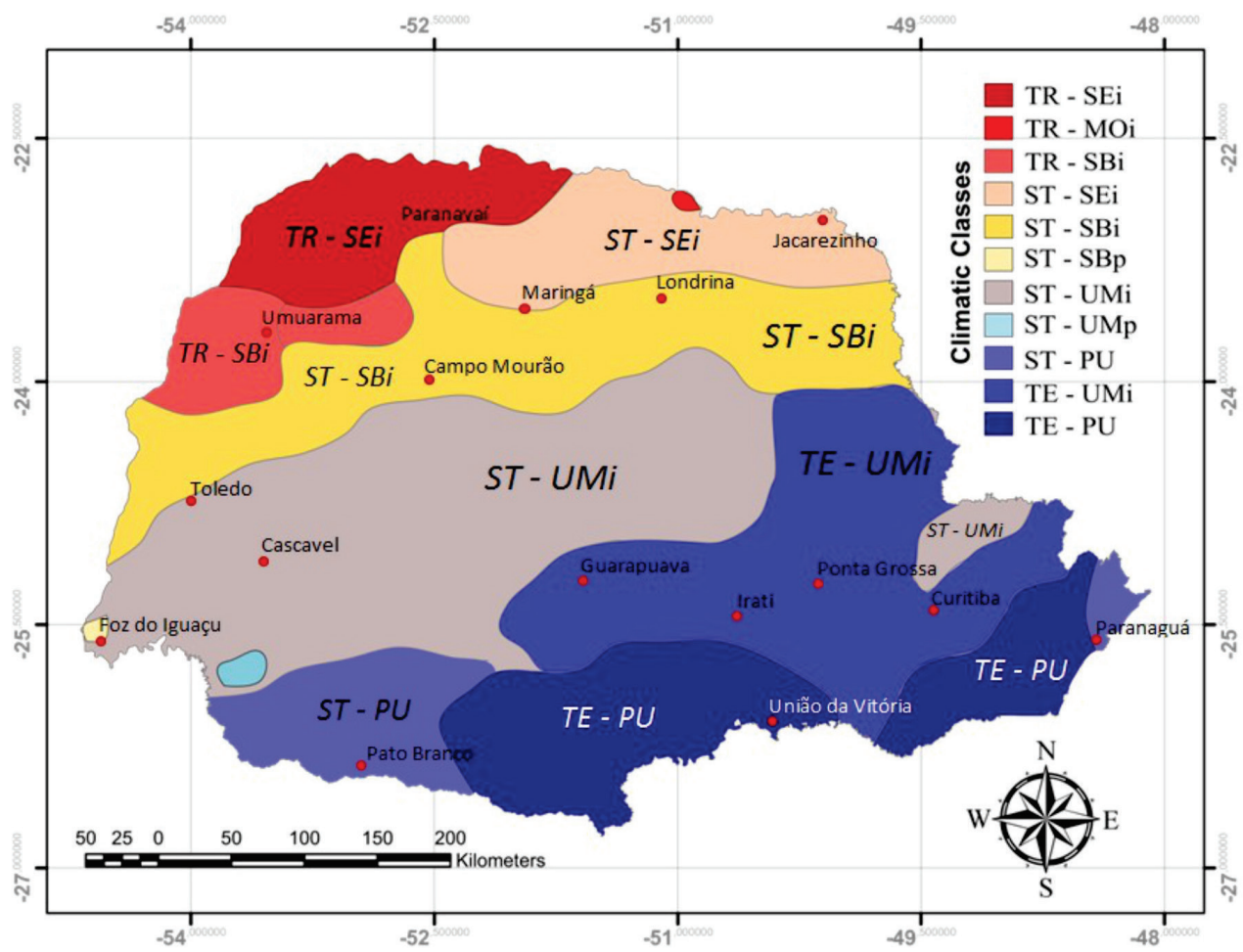

Figure 7: Climate zoning according to Camargo (1991) modified by Maluf obtained by ECMWF data.

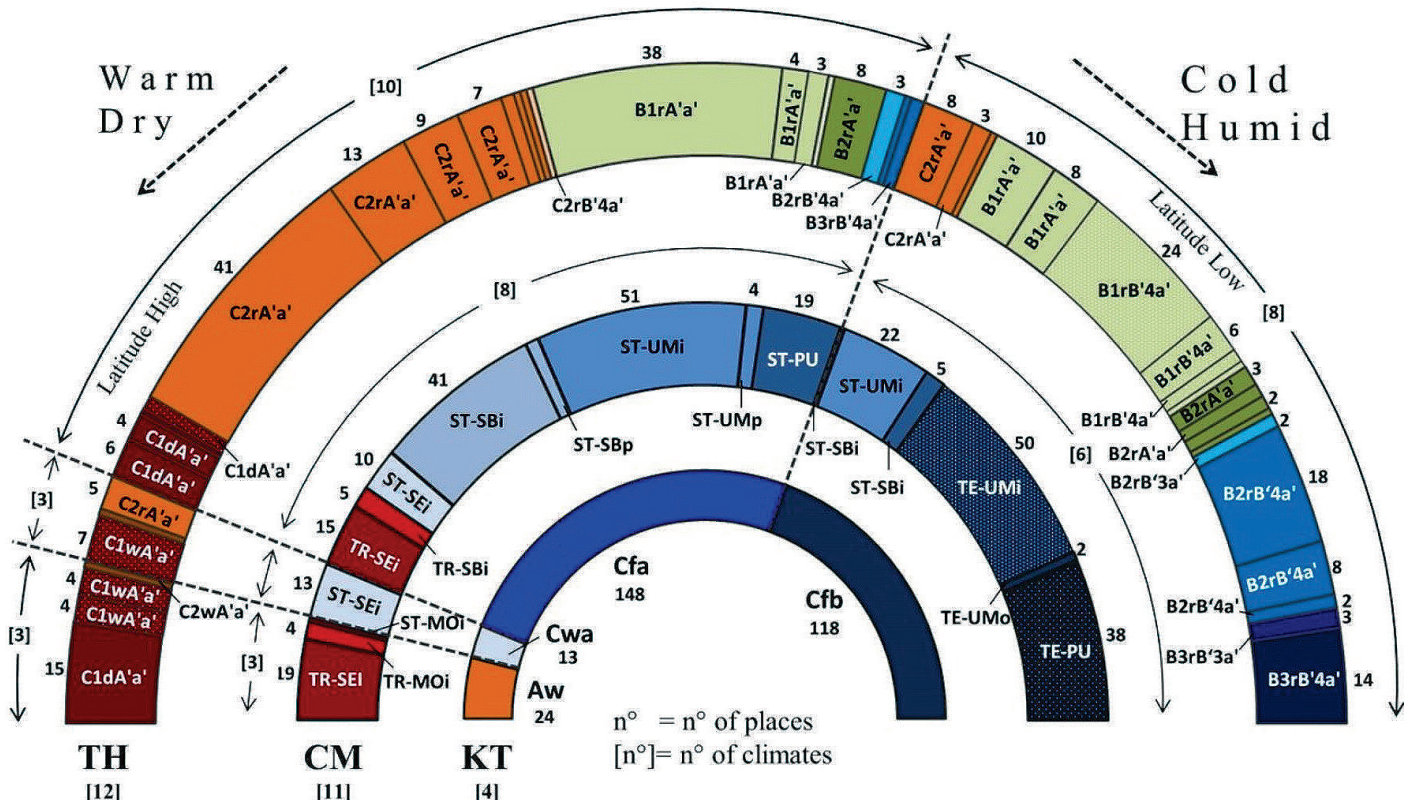

Figure 8: Equivalence of the classification systems of Thornthwaite (1948) (TH), Camargo (1991) modified by Maluf (2000) (CM) and, Köppen and Geiger (1928) modified by Trewartha (1954) (KT) of the State of Paraná, Brazil. Legend: The colors differentiate types of climates determined by each climatic classification system. The different plotted areas mean the percentage of locations in relation to the whole State; $n^{\circ}=$ numbers without brackets means number of locations and, $\left[n^{\circ}\right]=$ number with brackets means number of climates. 


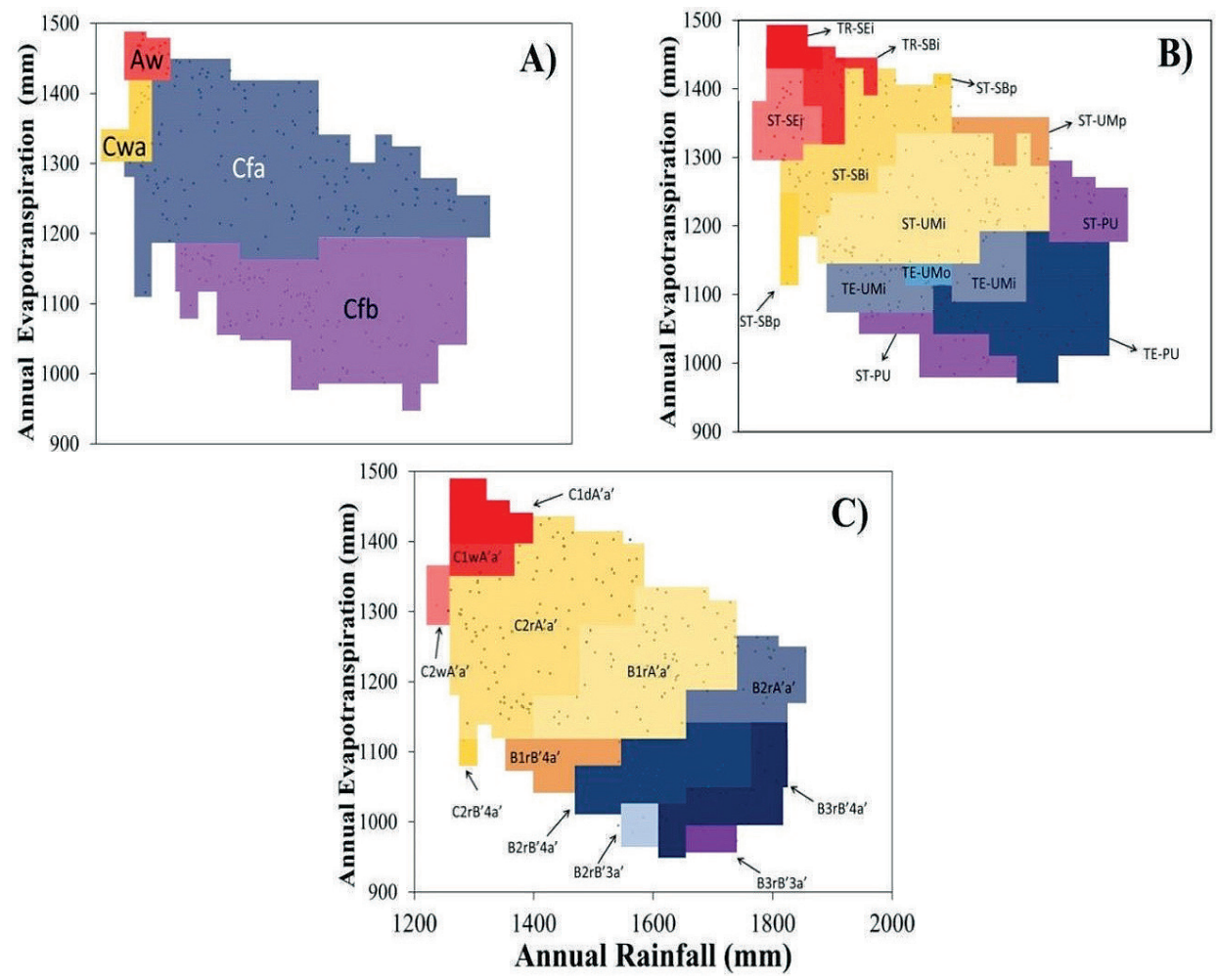

Figure 9: Climogram of annual rainfall and annual potential evapotranspiration of the climatical classification systems: A) Köppen and Geiger (1928) modified by Trewartha (1954), B) Camargo (1991) modified by Maluf (2000) and C) Thornthwaite (1948) of the State of Paraná, Brazil.

\section{CONCLUSIONS}

The description of climates in the State of Paraná was improved because we made classifications in macroand mesoscales using the virtual stations from the General Circulation Model-ECMWF. Climatic classifications were described in macroscale by the Köppen system and in mesoscale by the Thornthwaite and Camargo systems. A denser frame of ECMWF (virtual) stations brought an improvement in the accuracy of climate determination for the State. Climate classification systems separate warm and dry from cold and wet regions. Camargo (1991) modified by Maluf (2000) demonstrates efficiency in climatic separation equal to Thornthwaite (1948), but with a symbology of easy interpretation comparable to that of Köppen and Geiger (1928). The most predominant climates in the State of Paraná were the Cfa (temperate humid, hot in the summer), $\mathrm{C}_{1} \mathrm{rA}^{\prime} \mathrm{a}$ ' (sub humid with little water deficit) and ST - UMi (subtropical humid, dry in the winter), according Köppen and Geiger (1928) modified by Trewartha (1954), Thornthwaite (1948), and Camargo (1991) modified by Maluf (2000), respectively.

\section{REFERENCES}

ÁCS, F.; BREUER, H.; SKARBIT, N. Climate of Hungary in the twentieth century according to Feddema. Theor Appl Climatol. 115:3-4, 2014.

ALVARES, C. A. et al. Koppen's climate classification map for Brazil. Meteorologische Zeitschrift. 22:711-728, 2014.

BELDA, M. et al. Climate classification revisited: From Köppen to Trewartha. Climate Research. 59:1-13, 2014.

BIENIEK, P. A.; BHATT, U. S.; THOMAN, R. L. Climate divisions for Alaska based on objective methods. Journal of Applied Meteorology and Climatology. 51:1276-1289, 2012.

CAVALCANTI, I. F. A.; KOUSKY, V. E. Frentes frias sobre o Brasil. In: CAVALCANTI, I. F. A. et al. Tempo e Clima no Brasil. São Paulo: Oficina de textos.1:135-147, 2009.

CARVALHO, J. R. P.; ASSAD, E. D. Spatial analysis of precipitation data in São Paulo state: Comparison of interpolation methods. Engenharia Agrícola. 25(2):377-384, 2005. 
CARVALHO, J. R. P.; ASSAD, E.D.; PINTO, H.S. Interpoladores geoestatísticos na análise da distribuição espacial da precipitação anual e de sua relação com altitude. Pesquisa Agropecuária Brasileira. 47:1235-1242, 2012.

CAMARGO, A. P. de. Classificação climática para zoneamento de aptidão agroclimática. Revista Brasileira de Agrometeorologia. 8:126-131, 1991.

CONAB. National Supply Company 2015. Available in: http:// www.conab.gov.br/conteudos.php?a=1252\&. Access in: March, 12, 2016.

DE CASTRO, M. et al. The use of a climate-type classification for assessing climate change effects in Europe from an ensemble of nine regional climate models. Climatic Change. 81:329-341, 2007.

DOURADO, C. S.; OLIVEIRA, S. E. M.; ÁVILA, A. M. H. Analysis of rainfall homogeneous areas in time series of precipitation in the State of Bahia, Brazil. Bragantia. 72:192-198, 2013.

ELGUINDI, N. et al. Assessment of CMIP5 global model simulations and climate change projections for the 21st century using a modified Thornthwaite climate classification. Climatic Change. 122:523-538, 2014.

FEDDEMA, J. J. et al. The importance of land-cover change in simulating future climates. Science. 310:1674-1678, 2005

FLOHN, H. Neue Anschauungen über die allgemeine zirkulation der atmosphareund ihre klimatische bedeutung. Erdkunde. 4:141-162, 1950.

GALLARDO, C. et al. Assessment of climate change in Europe from an ensemble of regional climate models by the use of Koppen-Trewartha classification. International Journal of Climatology. 33:2157-2166, 2013.

GEIGER, R. Klassifikation der klimate nach W. Köppen. In: BARTELS, J.; BRUGGENCATE, P. Landolt- Börnstein Zahlenwerte und Funktionen aus physik, chemie, astronomie, Geophysik und Technik. Alte Serie. 3:603-607, 1954.

GENG, Q. et al. Comparison of classification methods for the divisions of wet/dry climate regions in Northwest China. International Journal of Climatology. 34:21632174, 2014

HOLDRIDGE, L. R. Life Zone Ecology. San Jose, Costa Rica: Tropical Science Center, 266 p. 1967.

INMET. National institute of meteorology. Standard Climatological (1961-1990) 2015. Available in: <http://www.inmet.gov.br/portal/index.php?r=clima/ normaisclimatologicas>. Access in: March, 10, 2016.
JACOBEIT, J. Classifications in climate research. Physics and Chemistry of the Earth. 35:411-421, 2010.

JYLHÄ, K. et al. Observed and projected future shifts of climatic zones in Europe, and their use to visualize climate change information. Weather, Climate and Society. 2:148-167, 2010.

KIM, H. J. et al. Changes in arid climate over North China detected by the Koppen climate classification. Journal of the Meteorological Society of Japan. Ser. II. 86:981-990, 2008.

KÖPPEN, W.; GEIGER, R. Klimate der Erde, Justus Perthes, Gotha. 1928.

KÖPPEN, W. Versuch einer klassifikation der klimate, vorzugsweise nach ihren beziehungen zur pflanzenwelt. Geographische Zeitschrif. 6:657-679, 1900.

KÖPPEN, W. Das Geographische System der Klimatologie. Berlin, 44 p. 1936.

KRIGE, D. G. A statistical approach to some basic mine evalution problems on the Witwatersrand. Johanesburg Chemistry Metallurgy Mining Society South Africa. 52:151-163, 1951.

LARSON, P. R.; LOHRENGEL, C. F. An addendum to "A new tool for climatic analysis using Köppen climate classification", Journal of Geography. 113:35-38, 2014.

LASLETT, G. M. Kriging and splines: an empirical comparison of their predictive perfomance in some applications. Journal of the American Statistical Association. 89:391-400, 1994.

MAHLSTEIN, I.; DANIEL, J. S.; SOLOMON, S. Pace of shifts in climate regions increases with global temperature. Nature Climate Change. 3:739-743, 2013.

MALUF, J. R. T. New climatic classification of the Rio Grande do Sul. Revista Brasileira de Agrometeorologia. 8(1):141150, 2000.

MINUZZI, R. B. CARAMORI, P. H. Seasonal and annual climatic variability of rainfall and dry spells in the state of Paraná, Brazil. Ceres. 58(5):593-602, 2011.

MORAES, R. A. et al. Evaluation of 10-day period precipitation, maximum and minimum air temperature data from the ECMWF model in sao paulo state. Brasilian Journal of Irrigation and Drainage. 17(3):397-407, 2012.

PEEL, M. C. et al. Updated world map of the Köppen-Geiger climate classification. Hydrology and Earth System Sciences. 11:1633-1644. 2007. 
PETERSEN, J. F.; SACK, D.; GABLER, R. E. Physical Geography Brooks/Cole Cengage Learning. Belmont, p.646, 2012.

RAHIMI, J.; EBRAHIMPOUR, M.; KHALILI, A. Spatial changes of extended De Martonne climatic zones affected by climate change in Iran. Theoretical and Applied Climatology. 112:409-418, 2013.

ROHLI, R. V.; VEGA, A. J. Climatology. 2nd ed. - Jones \& Bartlett Learning, Sudbury, 425p. 2012.

ROLIM, G. S.; APARECIDO, L. E. O. Camargo, Köppen and Thornthwaite climate classification systems in defining climatical regions of the state of São Paulo, Brazil. International Journal of Climatology. 36:636-643, 2015.

RODRIGUES, R. L.; MORETTO, A. C.; GUILhOtO, J. J. M. Productive and industry structure food in paraná, from 1980 to 1995 . Revista de Economia e Agronegócio. 4:241-266, 2015.

ROLIM, G. S. et al. Climatic classification of Köppen and Thornthwaite sistems and their applicability in the determination of agroclimatic zonning for the state of São Paulo, Brazil. Bragantia. 66:711-720, 2007.

SÁ JUNIOR, A. et al. Application of the Köppen classification for climatic zoning in the state of Minas Gerais, Brazil. Theoretical and Applied Climatology. 108:1-7, 2012.
SILVA, A. O.; MOURA, G. B. A.; KLAR, A. E. Climatic classification of Thornthwaite and its agro-climatic feasibility in different precipitation regimes in Pernambuco. Brazilian Journal of Irrigation and Drainage - IRRIGA. 19:46-60, 2014.

SPAROVEK, G.; VAN LIER, Q. J.; DOURADO, N. D. Computer assisted Koeppen climate classication: a case study for Brazil. International Journal of Climatology. 27:257-266, 2007.

SPINONI, J. et al. Towards identifying areas at climatological risk of desertification using the Köppen-Geiger classification and FAO aridity index. International Journal of Climatology. 35:2210-2222, 2014.

SRIVASTAVA, P. K. et al. Comparative assessment of evapotranspiration derived from NCEP and ECMWF global datasets through Weather Research and Forecasting model. Atmospheric Science Letters. 14:118-125, 2013.

THORNTHWAITE, C. W. An approach towards a rational classification of climate. Geographical Review. 38:55-94, 1948.

THORNTHWAITE, C. W., MATHER, J. R. The water balance. Publications in Climatology, 8(1), 104-114, 1955.

TREWARTHA, G. T. An Introduction to Climate. New York: McGraw-Hill. 402p. 1954.

VIOLA, M. R. et al. Spatial interpolation methods for mapping of rainfall. Revista Brasileira de Engenharia Agrícola e Ambiental. 14:970978, 2010. 